\title{
Effect of Heat-Treatment of Manganese Oxide Deposited on Stainless Steel 316L Current Collector Surface towards Carbon Based Supercapacitor Performance
}

\author{
B.N.M. Dolah, M. Deraman ${ }^{*}$, M. Suleman, M.A.R. Othman, M.R.M. Jasni, N.S.M. Nor \\ School of Applied Physics, Faculty of Science and Technology, Universiti Kebangsaan Malaysia, \\ 43600 Bangi, Selangor, Malaysia \\ *E-mail: madra@ukm.edu.my, mderaman113@gmail.com
}

doi: $10.20964 / 2017.03 .46$

Received: 11 November 2016 / Accepted: 13 January 2017 / Published: 12 February 2017

\begin{abstract}
Manganese oxide was deposited on the surface of stainless steel (SS) foil current collector (CC) using a simple immersion method followed by heat-treatment at three different temperatures $(70,200$ and $400{ }^{\circ} \mathrm{C}$ ) for $3 \mathrm{~h}$. The $\mathrm{CC}$ deposited with manganese oxide without and with heat treatment were used in symmetrical supercapacitor cells using highly porous activated carbon electrodes and $\mathrm{LiCl}$ electrolyte. The heat-treatment changes the structure (from amorphous to crystalline phase) and surface morphology of manganese oxide deposited on the $\mathrm{CC}$ surface as evidenced by X-ray diffraction and field emission scanning electron microscopy studies. The electrochemical impedance spectroscopy, cyclic voltammetry and galvanic charge-discharge characterization results of the supercapacitor cells demonstrate that the heat-treatment temperature of $70{ }^{\circ} \mathrm{C}$ results in a maximum increase of $\sim 70 \%$ in specific capacitance, $\sim 140 \%$ in specific power and $\sim 280 \%$ in specific energy compared to the cell using $\mathrm{CC}$ deposited with manganese oxide at room temperature. Further, a 10-fold decrement in response time (from $\sim 14$ to $\sim 1.4 \mathrm{~s}$ ) is achieved for a heat-treatment at $70{ }^{\circ} \mathrm{C}$ which implies a ten times faster delivery of energy. These results show the superiority of $\mathrm{CC}$ deposited with manganese oxide heat-treated at $70{ }^{\circ} \mathrm{C}$ over the manganese oxide deposited at other temperatures.
\end{abstract}

Keywords: Wet chemical deposition, Activated carbon; Supercapacitors; Manganese oxide; Electrochemical properties.

\section{$\underline{\text { FULL TEXT }}$}

(C) 2017 The Authors. Published by ESG (www.electrochemsci.org). This article is an open access article distributed under the terms and conditions of the Creative Commons Attribution license (http://creativecommons.org/licenses/by/4.0/). 